\title{
Adequacy assessment of mathematical models in the dynamics of litter decomposition in a tropical forest Mosaic Atlantic, in southeastern Brazil
}

\author{
Nunes, FP. ${ }^{a *}$ and Garcia, QS. ${ }^{b}$ \\ aPrograma de Pós-graduação em Ecologia, Conservação e Manejo de Vida Silvestre, \\ Universidade Federal de Minas Gerais - UFMG, Av. Presidente Antônio Carlos, 6627, \\ CEP 30161-970, Belo Horizonte, MG, Brazil \\ bLaboratório de Fisiologia Vegetal, Departamento de Botânica, Instituto de Ciências Biológicas - ICB, \\ Universidade Federal de Minas Gerais - UFMG, Av. Presidente Antônio Carlos, 6627, \\ CEP 30161-970, Sala 254, Belo Horizonte, MG, Brazil \\ *e-mail: flaviaperesnunes@yahoo.com.br
}

Received: May 5, 2013 - Accepted: April 25, 2014 - Distributed: May 31, 2015

(With 3 figures)

\begin{abstract}
The study of litter decomposition and nutrient cycling is essential to know native forests structure and functioning. Mathematical models can help to understand the local and temporal litter fall variations and their environmental variables relationships. The objective of this study was test the adequacy of mathematical models for leaf litter decomposition in the Atlantic Forest in southeastern Brazil. We study four native forest sites in Parque Estadual do Rio Doce, a Biosphere Reserve of the Atlantic, which were installed 200 bags of litter decomposing with $20 \times 20 \mathrm{~cm}$ nylon screen of $2 \mathrm{~mm}$, with 10 grams of litter. Monthly from 09/2007 to 04/2009, 10 litterbags were removed for determination of the mass loss. We compared 3 nonlinear models: 1 - Olson Exponential Model (1963), which considers the constant K, 2 - Model proposed by Fountain and Schowalter (2004), 3 - Model proposed by Coelho and Borges (2005), which considers the variable K through QMR, SQR, SQTC, DMA and Test F. The Fountain and Schowalter (2004) model was inappropriate for this study by overestimating decomposition rate. The decay curve analysis showed that the model with the variable $\mathrm{K}$ was more appropriate, although the values of QMR and DMA revealed no significant difference $(\mathrm{p}>0.05)$ between the models. The analysis showed a better adjustment of DMA using K variable, reinforced by the values of the adjustment coefficient $\left(\mathrm{R}^{2}\right)$. However, convergence problems were observed in this model for estimate study areas outliers, which did not occur with $\mathrm{K}$ constant model. This problem can be related to the non-linear fit of mass/time values to $\mathrm{K}$ variable generated. The model with $\mathrm{K}$ constant shown to be adequate to describe curve decomposition for separately areas and best adjustability without convergence problems. The results demonstrated the adequacy of Olson model to estimate tropical forest litter decomposition. Although use of reduced number of parameters equaling the steps of the decomposition process, no difficulties of convergence were observed in Olson model. So, this model can be used to describe decomposition curves in different types of environments, estimating $\mathrm{K}$ appropriately.
\end{abstract}

Keywords: litterfall, nutrient cycling, organic matter and nutrient loss, mathematical models, biosphere reserve.

\section{Adequação da utilização de modelos matemáticos em estudos da dinâmica de decomposição da serapilheira em um Mosaico de Floresta Tropical Atlântica, no sudeste do Brasil}

\footnotetext{
Resumo

O estudo da ciclagem de nutrientes através da decomposição de serapilheira é essencial para conhecer a estrutura e funcionamento das florestas tropicais nativas. Em decorrência da sua dependência de variáveis ambientais, o uso de modelos matemáticos pode ajudar a compreender as variações locais e temporais da decomposição do folhedo. $\mathrm{O}$ objetivo deste estudo foi testar a adequação dos modelos matemáticos para avaliar a dinâmica da decomposição da serapilheira em um mosaico de Floresta Tropical Atlântica no sudeste do Brasil. O estudo foi realizado em quatro remanescentes de mata nativa no Parque Estadual do Rio Doce, parte da Reserva da Biosfera da Mata Atlântica, onde se instalou 200 bolsas decompositoras feitas de tela de nylon $20 \times 20 \mathrm{~cm}$ de $2 \mathrm{~mm}$, com 10 gramas de serapilheira recém-colhida. Mensalmente, de 09/2007 a 04/2009, 10 litterbags foram removidos por área, para limpeza, secagem e posterior determinação da perda de massa. Comparamos três modelos não lineares: 1 - Modelo exponencial de Olson (1963), que considera a constante K, 2 - Modelo proposto por Fountain and Schowalter (2004), 3 - Modelo proposto
} 
por Coelho e Borges (2005), que considera a variável K através do QMR, SQR, SQTC, DMA e Teste F. O modelo de Fountain and Schowalter (2004) mostrou-se inadequado por superestimar a taxa de decomposição. A análise mostrou que a curva de decaimento do modelo com $\mathrm{K}$ variável foi o mais adequado, embora os valores de QMR e DMA não revelaram nenhuma diferença significativa $(\mathrm{p}>0,05)$ entre os modelos. A análise mostrou um melhor ajustamento do DMA usando a variável $\mathrm{K}$, que foi reforçada com os valores do coeficiente de calibração $\left(\mathrm{R}^{2}\right)$. No entanto, problemas de convergência foram observados neste modelo, que não foi capaz de estimar com precisão os valores "outliers" para cada área de estudo, o que não ocorreu com o modelo de Olson. Entretanto, parece que os problemas de não convergência podem estar relacionados ao ajuste não linear dos dados de massa por tempo, utilizados para gerar o modelo. Quando submetido ao ensaio de parâmetros iguais, o modelo com K constante (Olson, 1963) mostrou-se adequado para descrever a curva de decomposição por áreas de estudo separadamente, de modo que o seu melhor ajuste não compensou os problemas de convergência encontrados. Os resultados demonstraram a aptidão do modelo proposto por Olson (1963) para estimar a decomposição de serapilheira de florestas tropicais, mesmo que eventualmente não detecte diferenças entre as etapas do processo de decomposição. Este modelo não apresenta dificuldades de convergência, permitindo descrever as curvas de decomposição em diferentes tipos de ambientes, estimando os valores de $\mathrm{K}$ mais apropriadamente e com mais acurácia.

Palavra-chave: decomposição de serapilheira, ciclagem de nutrientes, degradação de matéria orgânica e nutrientes, modelo matemático, reserva da biosfera.

\section{Introduction}

Litter production and fall are an essential process to ecosystem forest maintenance and soil fertility (Ewel, 1976). It is the main way for organic matter and nutrients cycling (Stocker et al., 1995), for providing more stability to the system (Jordan and Kline, 1972). The nutrient mineralization provided by soil degradation of biomass growth largely determines the characteristics of dominant species in an ecosystem (Hoorens et al., 2002). Although tropical ecosystems show nutrient cycling fast (Wood et al., 2009), the litter production and decomposition depends to the type and succession ecosystem stage (Olson, 1963). The litter deposition is determined by the characteristics of the vegetation, increasing up to the maturity trees (Vital et al., 2004), and decreasing or stabilizing after that point (Bray and Gorham, 1964). Decomposition is governed by soil conditions, environmental factors and the quality of the substrate (Souza and Davide, 2001), which are controlled by climatic variables. As a process dependent on various environmental factors, it is difficult to model and predict adequately over time.

The use reduce the set of models can be an excellent tool to describe biological processes in different types of situations (Regazzi and Silva, 2004; e.g. Borges et al., 2008). Especially the use of the regression over time, using non-linear models, reduces the set of information involved in a biological process, such as those associated with the time, a few biologically interpretable parameters (Sarmento et al., 2006). Considering the influence of local variables in the model decomposition, the use of parameters can facilitate comparisons between different types of environment and ecosystems (Liski et al., 2003). In general, mathematical models considers uniform process, with decay coefficient or factor decomposition constant for any time (Coelho and Borges, 2005). This assumption was confirmed by studies that relate the role of decomposition processes with varies according the types of compounds, along the loss of biomass (Middelburg, 1989; Paustian et al., 1997).
Thus, although represent an excellent tool for estimating and predicting biological processes (Sarmento et al., 2006), the inappropriate application of a model can change the values, overestimating or underestimating the results. This study aimed to test the adequacy of mathematical models to study litter decomposition in southeastern Brazil Atlantic Forest.

\section{Material and Methods}

\subsection{Study area}

The work was conducted at Parque Estadual do Rio Doce - PERD (19 $29^{\prime} 24^{\prime \prime}-19^{\circ} 48^{\prime} 18^{\prime \prime}$ S and $\left.42^{\circ} 28^{\prime} 18^{\prime \prime}-42^{\circ} 38^{\prime} 30^{\prime \prime} \mathrm{W}\right)$, Atlantic Biosphere Reserve (IEF, 1994), whose ecological importance and extent justify its use as a model for ecological studies in tropical forests. The climate of PERD, according to the Köppen classification, fits the type AW - Semi-Tropical Hot Wet (IEF, 1982). The rainy season, from October to March, has accumulated rainfall of $1,250.0 \mathrm{~mm}(84.5 \%$ of the year), with average maximum temperatures of $24.7^{\circ} \mathrm{C}$. The dry season, from May to September, shows average rainfall of $134.9 \mathrm{~mm}(9.1 \%)$, with an average minimum temperature of $18.8^{\circ} \mathrm{C}$ (Gilhuis, 1986). We have four areas of native forest: "Lagoa Preta" (Area 1), "Lagoa Central" (Area 2) "Garapa Torta" (Area 3) and "Aníbal" (Area 4), who composed the plots sample of Tropical Ecology, Assessment and Monitoring (TEAM) Initiative (Kuebler, 2005), composing the park landscape diversity and physiognomy, differing in relation to the conservation status of the vegetation (Metzker, 2007).

\subsection{Methodology}

\subsubsection{Decomposition of litter}

The litter decomposition was evaluated using litterbags with 10 grams of dry and homogenized leaf litter, collected between August/2005 and July/2006 in the study areas, confined in "litterbags" $20 \times 20 \mathrm{~cm}$ nylon mesh $2 \mathrm{~mm}$ (Anderson and Ingram, 1996). Monthly 
between September 2007 and April 2009, were removed 10 litterbags/area, stored in plastic bags and taken to the laboratory, opened and cleaned for removing waste soil and other contaminants for subsequent oven drying and determination of mass loss (Anderson and Ingram, 1996). Three nonlinear (exponential) mathematical models were tested to describe leaf litter decomposition.

Initially, we tested the exponential model of Olson (1963), who propose a K constant for decomposition period, whereby $\mathrm{X}_{\mathrm{t}} / \mathrm{X}_{0}=\mathrm{X}_{0} \mathrm{e}^{-\mathrm{kt}}$. Subsequently, we tested the model proposed by Fonte and Schowalter (2004), which suggests the use of a correction factor to describe the decomposition of $20 \%$ initial biomass, resulting in $\mathrm{Ln}(\mathrm{Xt} / \mathrm{X} 0)=-\mathrm{Kt}+$ Yint. Coelho and Borges (2005) model suggests a $\mathrm{K}$ variable over time according to the decomposition processes. In this model, $\mathrm{k}$ is obtained by non-linear fit to the data of mass/time, efficient since the number of parameters is not greater than 4 (Silva Neto and Moura Neto, 2005).

For obtain the best fit of collect data, we compared models through the mean square (QMR), residual sum of squares (SQR), total sum of squares corrected for the mean (SQTC) and mean absolute deviation of the residues (DMA), according Sarmento et al. (2006). To test the adequacy of models we used the F-test, which assesses whether the increased SQR caused by the use of a model. The comparisons between the mathematical models and the areas were made using the SAS System software, with $95 \%$ of significance level.

\section{Results and Discussion}

Litter decomposition resulted in lower biomass remaining in Area 1 ("Lagoa Preta"-1.75 g, 19\%); witch differed from the others sites (Tukey: $p=0.046$ ). Area 2 ("Lagoa Central" - 2.62 g, 21\%), Area 3 ("Garapa Torta", $2.83 \mathrm{~g}, 22 \%$ ) and Area 4 ("Lagoa Aníbal" - 3.14 g, 25\%) were similar (Tukey: $\mathrm{p}=0.642$, Figure 1 ).

These reflected in decomposition constant $(\mathrm{K})$ similar among areas $(\mathrm{p}>0.05)$, in the same sequency: Area $1(\mathrm{~K}=1.64)$, Area $2(\mathrm{~K}=1.51)$, Area $3(\mathrm{~K}=1.46)$ e Area $4(\mathrm{~K}=1.46)$, and similar behavior during all the period. Area $4(\mathrm{~F}=0.838)$ and $3(\mathrm{~F}=0.847)$ had linear behavior than Area $1(\mathrm{~F}=0.657)$ and $2(\mathrm{~F}=0.639)$, indicating the decomposition dynamics was uniform throughout the process in this two sites. More marked differences were observed in the last quarter period, probably with the carbon cycle in the last of decomposition process.

The mathematical model described by the equation $\mathrm{Ln}(\mathrm{Xt} / \mathrm{X} 0)=-\mathrm{Kt}+$ Yint proved to be inadequate to overestimation decomposition rate. Fonte and Schowalter
(2004) suggested this model, adapted by Olson model, minimizing the effect of the $20 \%$ initial rapid decay in the calculation $\mathrm{K}$ decomposition. For this problem, they suggest using a correction factor. However, this proposition has been made based on studies that have assessed 15 days, the time required for this part of the biomass disappearing, resulting in poor performance of traditional models to describe decomposition. To fix this error, they proposed to use adjustment factor to compensate for the sharp initial loss, allocating the term interceptor "Yint" to indicate the initial loss by leaching (Sullivan et al., 1999). Although our results were obtained in a tropical region, where decomposition was significantly more slowly, recording the $20 \%$ decomposition of starting material to approximately 4 months of study. Thus, the application of the mathematical model proposed by Fonte and Schowalter (2004) overestimate the speed and constant decomposition, inadequate to describe the decomposition curve and initial mass loss, disagree with the authors. Through the application of leaf litter decay curve models proposed by Olson (1963), with constant K, and Coelho and Borges (2005), with variable K, the mathematical parameters showed that the second model best described the decomposition process (Table 1), although they showed no significant differences between the groups ( $\mathrm{p}>0.05)$.

The values of QMR and DMA revealed no significant difference $(p>0.05)$ between the models, which differed only 1.16 and $1.14 \%$ of each other, respectively. The DMA analysis allowed us to observe small differences between the models, with lower values indicating better ability to adjust average model, as obtained by considering the $\mathrm{K}$ variable. Analysis of the coefficient of adjustment (R2) showed that the models are set similarly to the mean curve of general decomposition when analyzed values of the subject areas together. So, that the models differ only at the end of the process (Figure 2).

The analysis of the distribution of residuals (Figure 3) showed greater deviation in fit obtained by the model with

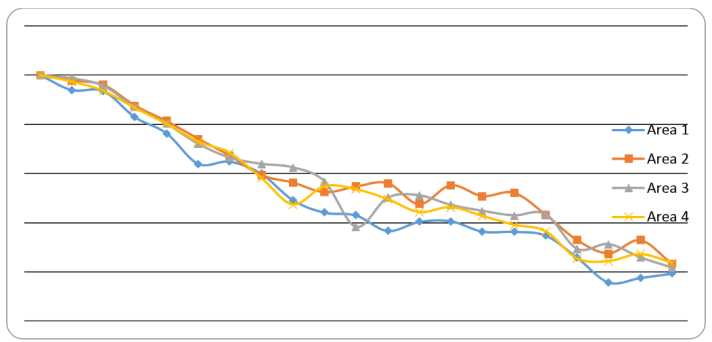

Figure 1. Litter decomposition in study sites sampled in the Rio Doce State Park, Minas Gerais, Brazil, between August/07 April/09.

Table 1. Estimates of the parameters mean square (QMR), coefficient of determination (R2) and mean absolute deviation (DMA) maximum, minimum and average, according to the models studied.

\begin{tabular}{cccccc}
\hline Model & QMR & $\mathbf{R}^{\mathbf{2}}$ & DMA min & DMA max & DMA mean \\
\hline K Constant & 0.874 & 0.857 & 0.0006 & 3.9719 & 0.711 \\
K variable & 0.864 & 0.859 & 0.0008 & 3.9160 & 0.703 \\
\hline
\end{tabular}


constant $\mathrm{K}$, and the slightest deviation model with variable $\mathrm{K}$, although this difference was significant $(\mathrm{p}<0.05)$ only at the end of period of decomposition in the last three months of study.

Despite the similarity in most of the decomposition period between the models, the comparison between them through the $\mathrm{F}$ test indicated significant differences $(p<0.0001)$. However, the model with $\mathrm{K}$ variable showed convergence problems, unable to estimate the outliers for each study area, which did not happen with $\mathrm{K}$ constant model. Thus, although the best model obtained by adjust the variable $\mathrm{K}$, this cannot represent decomposition curve, whereas the difference in quality was poor fit to overcome the difficulty in achieving convergence. Probably this occurred why models have convergence difficulties to estimate biological parameters were also reported by Braccini Neto et al. (1996) and Sarmento et al. (2006). Authors showed that, despite the greater flexibility when considering a larger number of variables, not to fix the point of inflection, complex models have more difficulty in the interactive process in their adjustment. However, the problems of convergence with variable $\mathrm{k}$ can be a consequence of the non linear fit of the data mass per time values.

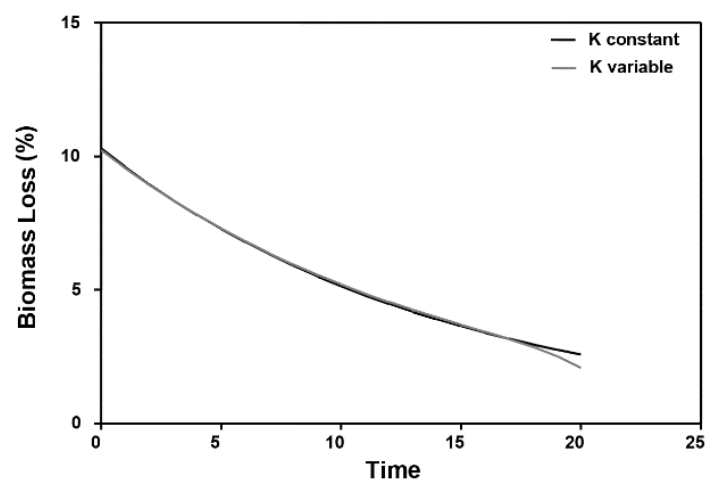

Figure 2. Residual Dispersion curve general decomposition for all the study areas, according to the model with constant $\mathrm{K}$ and $\mathrm{K}$ variable.

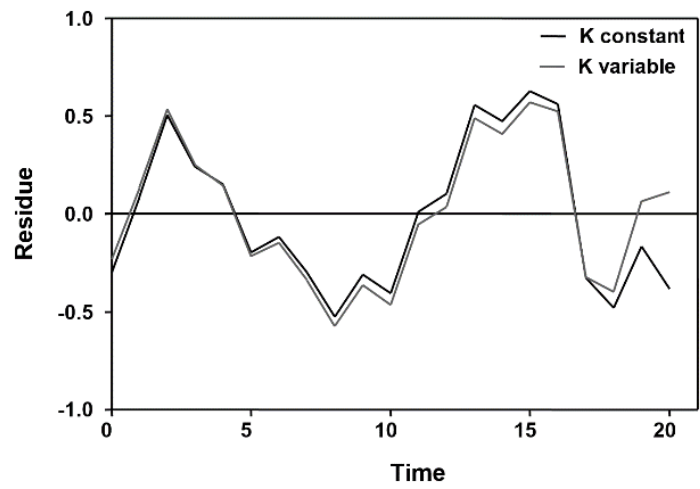

Figure 3. Residual Dispersion curve general decomposition for all the study areas, according to the model with constant $\mathrm{K}$ and $\mathrm{K}$ variable.
The equality test model parameters applied to Olson (1963), comparing the decay curves of the areas of study, it was verified that was null hypothesis Ho, significant differences $(\mathrm{p}<0.05)$ in the decomposition curve study areas (Table 2).

This test demonstrates the model ability for describing the decomposition curve, based consider the equality of parameters on the hypothesis Ho, as described by Sarmento et al. (2006). The results showed that even ignores possible differences in the rate of decomposition over time, he differentiated areas of study and did not act to accentuate the statistical error. Regarding the estimate made by the decomposition model, the largest differences were obtained between areas 1 and 3 and between the lower areas 2 and 4, reflecting the $\mathrm{K}$ values obtained (Table 3).

The highest values of $\mathrm{K}$ were obtained in Area 1, in contrast with the Area 3, which had the lowest rate of decomposition. Although different, all areas studied had values below the expected for tropical ecosystems, not similar only in the last time of decomposition role.

Vital et al. (2004) found that the decomposition rate of 1.71 , considered high values seconds Olson (1963), which set values above 1.00 for high rates of decomposition. Pagano (1989) suggested that larger values of $K=1.15$ can now be considered high for regions of the Atlantic, while other jobs are less stringent, considering values of $\mathrm{K}>0.01$ rapid decomposition (Liski et al., 2003).

The results demonstrated the suitability of the model proposed by Olson (1963) to estimate the decomposition of leaf litter in tropical forests, although this is the more simplified model among those tested in this work, as equals stages of the decomposition process, reducing the variations to a only constant decomposition. The reduction of the parameters used by the model, although become less sensitive to variations in the process, increase its ease

Table 2. Test of equality of parameters between the study areas, applied to the model of Olson (1963).

\begin{tabular}{ccccc}
\hline Ho & F & F tab & Parameters & \multicolumn{1}{c}{$\mathbf{P}$} \\
\hline $\mathrm{K} 1=\mathrm{K} 2=$ & 39.253 & 3.813 & 2 & $\mathrm{p}<0.0001$ \\
$\mathrm{~K} 3=\mathrm{K} 4$ & & & & \\
$\mathrm{~K} 1=\mathrm{K} 2$ & 62.198 & 1.813 & 4 & $\mathrm{p}<0.0001$ \\
$\mathrm{~K} 1=\mathrm{K} 3$ & 107.611 & 1.813 & 4 & $\mathrm{p}<0.0001$ \\
$\mathrm{~K} 1=\mathrm{K} 4$ & 25.894 & 1.813 & 4 & $\mathrm{p}<0.0001$ \\
$\mathrm{~K} 2=\mathrm{K} 3$ & 6.246 & 1.813 & 4 & $\mathrm{p}<0.01$ \\
$\mathrm{~K} 2=\mathrm{K} 4$ & 5.335 & 1.813 & 4 & $\mathrm{p}<0.02$ \\
$\mathrm{~K} 3=\mathrm{K} 4$ & 23.032 & 1.813 & 4 & $\mathrm{p}<0.0001$ \\
\hline
\end{tabular}

Table 3. Values of the constant decomposition obtained through the model of Olson (1963).

\begin{tabular}{ccc}
\hline Area & $\mathbf{K}$ & $\mathbf{p}<\mathbf{0 , 0 5 *}$ \\
\hline 1 & 0.0818 & $\mathrm{a}$ \\
2 & 0.0659 & $\mathrm{~b}$ \\
3 & 0.0614 & $\mathrm{c}$ \\
4 & 0.0702 & $\mathrm{~d}$ \\
\hline
\end{tabular}

*Areas identification acording $\mathrm{k}=\mathrm{P}<0,05$. 
of adaptation to different decay curves. Thus, this model showed no convergence problems, as occurred for the mathematical models used a wider range of parameters for estimation of the decomposition curve, considering the unit $\mathrm{K}$ as a variable over time.

\section{Acknowledgements}

Ao CNPq pelo financiamento do projeto (PELD/CNPq processo 520031/98-9); à CAPES pela concessão da bolsa de doutorado, ao Programa de Pós-graduação em Ecologia, Conservação e Manejo da Vida Silvestre pelo apoio.

\section{References}

ANDERSON, JD. and INGRAM, JSI., 1996. Tropical soil biology and fertility: a handbook of methods. 2nd ed. Wallingford: CAB International.

BORGES, PAP., VIONE, MT. and CERVI, A., 2008. Determinação dos coeficientes do modelo de Van Genuchten empregando o problema inverso. In Anais do VIII Encontro Regional de Matemática Aplicada e Computacional, 2008. Natal. Pelotas: SBMAC.

BRACCINI NETO, J., DIONELLO, NJL. and SILVEIRA JUNIOR, P., 1996. Análise de curvas de crescimento de aves de postura. Revista da Sociedade Brasileira de Zootecnia, vol. 25, no. 6, p. 1062-1073.

BRAY, JR. and GORHAM, E., 1964. Litter production in forest of the world. Advances in Ecological Research, vol. 2, p. 101-157. http://dx.doi.org/10.1016/S0065-2504(08)60331-1.

COELHO, GC. and BORGES, PAP., 2005. Mathematical modeling of the litter decomposition and accumulation in a forest plantation: the transient case. In MONDAINI, R. and DILÃO, R. (Eds.). Proceedings of the 2005 International Symposium on Mathematical and Computational Biology, 2005. Rio de Janeiro. Rio de Janeiro: E-paper.

EWEL, JJ., 1976. Litter fall and leaf decomposition in a tropical forest succession in eastern Guatemala. Journal of Ecology, vol. 64, no. 1, p. 293-308. http://dx.doi.org/10.2307/2258696.

FONTE, SJ. and SCHOWALTER, TD., 2004. Decomposition of Greenfall vs. Senescent Foliage in the Tropical Forest Ecosystem in Puerto Rico. Biotropica, vol. 36, no. 4, p. 474-482. http://dx.doi. org/10.1111/j.1744-7429.2004.tb00343.x.

GILHUIS, JP., 1986. Vegetation survey of the Parque Estadual do Rio Doce, MG, Brazil. Viçosa: Universidade Federal de Viçosa; Netherlands: Agricultural University of Wageningen. 86 p.Master's Thesis in Agriculture.

HOORENS, B., AERTS, R. and STROETENGA., 2002. Litter quality and interactive effects in litter mixtures: more negative interactions under elevated CO2? Journal of Ecology, vol. 90, no. 6, p. 1009-1016. http://dx.doi.org/10.1046/j.1365-2745.2002.00732.x.

Instituto Estadual de Florestas - IEF, 1982. Vegetation survey of the Parque Estadual do Rio Doce. Belo Horizonte: Fundação Centro Tecnológico de Minas Gerais.

Instituto Estadual de Florestas - IEF, 1994. Research priorities for the Parque Estadual do Rio Doce, Brazil. Belo Horizonte: IEF.

JORDAN, CF. and KLINE, JR., 1972. Mineral Cycling: some basic concepts and their applications in the tropical rain forest. Annual
Review of Ecology and Systematics, vol. 3, no. 1, p. 33-50. http:// dx.doi.org/10.1146/annurev.es.03.110172.000341.

KUEBLER, CMFS., 2005. Tropical ecology, assessment and monitoring initiative: litterfall phenology and standardized monitoring protocol. Washington: Program Manager, TEAM Initiative/ The Center for Applied Biodiversity Science (CABS)/ Conservation International. Vegetation Monitoring Protocol, Version 2.0.

LISKI, J., NISSINEN, A., ERHARD, M. and TASKINEN, O., 2003. Climatic effects on litter decomposition from arctic tundra to tropical rainforest. Global Change Biology, vol. 9, no. 4, p. 575-584. http://dx.doi.org/10.1046/j.1365-2486.2003.00605.x.

METZKER, TI., 2007. Studies on the dynamics and carbon stocks of the Atlantic forest of Parque Estadual do Rio Doce - Minas Gerais, Brazil. Belo Horizonte: ICB / UFMG. Master's Thesis in Ecology Conservation and Wildlife Management.

MIDDELBURG, J.J., 1989. A simple rate model for organic matter decomposition in marine sedments. Geochimica et Cosmochimica Acta, vol. 53, no. 7. p. 1577-1581.

OLSON, JS., 1963. Energy storage and the balance of producers and decomposers in ecological system. Ecology, vol. 44, no. 2, p. 322-331. http://dx.doi.org/10.2307/1932179.

PAGANO, SN., 1989. Produção de folhedo em mata mesófila semi-decídua no município de Rio Claro, SP. Brazilian Journal of Biology $=$ Revista Brasileira de Biologia, vol. 49, p. 633-639.

PAUSTIAN, K., AGREN, GI. and BOSSATA, E., 1997. Modelling litter quality effects on decomposition and soil organic matter dynamics. In KADDISH, G. and GILLER, KE. (Eds.). Driven by nature: plant litter quality and decomposition. Cambridge: $\mathrm{CAB}$ International. p. 313-335.

REGAZZI, AJ. and SILVA, CHO., 2004. Teste para verificar a igualdade de parâmetros e a identidade de modelos de regressão não-linear. I. Dados no delineamento inteiramente casualizado. Revista de Matemática e Estatística, vol. 22, no. 3, p. 33-45.

SARMENTO, JLR., REGAZZI, AJ., SOUSA, WH., TORRES, RA., BREDA, FC. and MENEZES, GRO., 2006. Estudo da curva de crescimento de ovinos Santa Inês. Revista Brasileira de Zootecnia, vol. 35, no. 2, p. 435-442. http://dx.doi.org/10.1590/ S1516-35982006000200014.

SILVA NETO, AJ. and MOURA NETO, FD., 2005. Problemas inversos: conceitos fundamentais e aplicações. Rio de Janeiro: UERJ.

SOUZA, JA. and DAVIDE, AC., 2001. Litterfall and nutrients in a forest not mined and bracatinga plantations and eucalyptus in the mining of bauxite. Cerne, vol. 7, no. 1, p. 101-114.

STOCKER, GC., THOMPSON, WA., IRVINE, AK., FITZSIMON, JD. and THOMAS, PR., 1995. Annual patterns of litterfall in a Lowland Rainforest in Tropical Tableland and Australia. Biotropica, vol. 27, no. 4, p. 412-420. http://dx.doi.org/10.2307/2388952.

SULLIVAN, NH., BOWDEN, WB. and MCDOWELL, WH., 1999. Short-term disappearance of foliar litter in three species before and after the hurricane. Biotropica, vol. 31, no. 3, p. 382-393. http:// dx.doi.org/10.1111/j.1744-7429.1999.tb00380.x.

VITAL, ART., GUERRINI, IA., FRANKEN, WK. and FONSECA, RCB., 2004. Litter production and nutrient cycling in a semideciduous forest in Riparian Zone. Revista Árvore, vol. 28, no. 6, p. 793-800.

WOOD, TE., LAWRENCE, D., CLARK, DA. and CHAZDON, RL., 2009. Rain forest nutrient cycling and productivity in response to large-scale litter manipulation. Ecology, vol. 90, no. 1, p. 109-121. http://dx.doi.org/10.1890/07-1146.1. PMid:19294918 